\title{
Design an expert system for students graduation projects in Iraq universities: Basrah University
}

\author{
Maysaa Abd Ulkareem Naser, Sajad Mohammed Hasen
}

Department of Computer Information System, University of Basrah, Iraq

\begin{tabular}{l} 
Article Info \\
\hline Article history: \\
Received Apr 9, 2020 \\
Revised Jun 18, 2020 \\
Accepted Aug 5, 2020 \\
\hline
\end{tabular}

\section{Keywords:}

Distribution of students

Graduate attributes

Graduation project

Problems that system treat

Registration document

\begin{abstract}
A graduation project is a form or work that the study authority requests from the student to measure what he made during the study. Designed an expert system for students' graduation projects at the University of Basrah for students who are obligated to submit a project that qualifies them to graduate from the university. The system works according to a set of requirements, the most important is first: The student's possession of a high rate that qualifies him for the project. Second: he must possess half of the skills required for the project provided that it includes at least one programming language example (c ++, java, PHP, c \#, etc ...). The system has many features that help the Supervisors and Students Committee to manage students' projects efficiently. System is built as a web-based system, with access limited only to the university's local network.
\end{abstract}

This is an open access article under the CC BY-SA license.

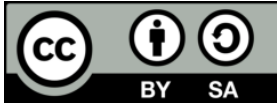

\section{Corresponding Author:}

Maysaa Abd Ulkareem Naser,

Deprtement of Computer Information System,

University of Basrah,

The Site of Karma Ali, Iraq.

Email: maysaakarem13@gmail.com

\section{INTRODUCTION}

The graduation project is a project that the study authority requests from students before obtaining a university certificate, graduate attributes have been taking momentum since the early 20th century. One of the most commonly used definitions of graduating attributes (GAs) suggested by Bowden et al. says: "Graduate attributes are the qualities, skills ,and understandings a university community agrees its students should develop during their time with the institution" [1]. the aim of which is to identify the extent of the student's understanding of what has been studied within the corridors of the university, and to measure his ability to creativity [2], and there are some universities suppor the work for more than one student [3], and this must be completed Research in a specific period under the supervision of a university professor [4]. Most computer science programs at the undergraduate level require a compulsory "graduation project" course that students must take in the third or fourth year of study.

In the College of Computer Science and Information Technology, each student is required to develop a project, implement a model system, and write a research report in one semester. The projects are distributed according to mechanisms that depend on points (student average, skills that he owns it in the field of Computer Science and Information Technology) supervisors should assist their students to complete the project, and guide them through the main stages of the graduation project. Thus, supervisors and other participants will be involved to track student work and progress [5-7]. For this purpose, we design an expert system, based on the students' skills the have to make an appropriate decision in distributing projects to students. An expert system is "a computer program that uses knowledge and inference procedures to solve problems that are ordinarily solved through the human expert" [8]. With the rapid growth and unfold of 
information and communique technology (ICT), professional systems have evolved that have completely reshaped the web revel in users by supplying meaningful, effective, and personalized advice of services and products to users. Through proper statistics modeling and analysis, recommender systems tend to aid users in selection making strategies by enhancing their capability and first-class of thinking $[9,10]$.

Expert systems are widely implemented in various fields, including for student career steering on factors of educational guidance, educational assessment, academic career guidance and vocational career steering, such as: recognizing student characteristics [11], student overall performance analysis [12], student overall performance predictions [13], basic assessment of student competence [14], character-based educational assessment [15], and assessment of academic programs [16]. Crucial decisions for a college student are a hard and time-consuming task because many elements make contributions to correct selection making, together with: student grades, personality, talents, skills, preferences, subjects of interest, so students need to get assist from the recommendation system to pick out the proper project $[17,18]$. This research was motivated by the idea that successfully being able to develop a Distribution of graduation projects to student's system of this nature, will increase the breadth and scope of students and academic staff problems solved, and subsequently academic activities can successfully be achieved to an excellent level in the university learning process. The system is designed at the University of Basra for students who are obligated to submit a project that qualifies them to graduate from the university. The system works according to a set of requirements, the most important is first: The student's possession of an average that qualifies him for the project. Second: Possesses programming skills required for the project, example (c ++, java, PHP, c \#, etc ...).

Literature review for Many researchers presented research, one of them represent Implementing the graduation project management system based on" Moodle software" permit to study the communications between the shareholders of the system [19]. Moreover, an academic project management web-based system is developed by Letouze using JAVA, Javaserver, Primefaces, PostgreSQL, Glassfish and Netbeans. It is additionally defined as "one of the most used and powerful databases on the web today" [20]. Another researcher worked a research program that allows students to register in research in exchange for course credits [21]. Another study the focus of the research of studies associated with the impact of the utility of professional systems in pupil steerage on aspects of educational guidance, educational evaluation and factors of instructional career steering and work guidance [22].

Aim of the research is the importance of the graduation project management system in facilitating communication between the project committee and supervisors, and between students and supervisors, and solving the conflict problem, which is one of the biggest problems in the distribution of projects when selecting more than one group for the same project additionally by another benefit The paper is organized as follows: Section1 presents an introduction \& literature review. Section 2 of the graduation project Course. Section 3 describes the method of system Section 4 discussion and result.

\section{METHOD OF SYSTEM}

To the better of our knowledge, software for managing graduation projects is an incredibly new idea. A tremendous deal of studies of an exploratory and descriptive nature is needed, as shown in Figure 1 representing the overall system structure for the distribution of graduation projects to students.

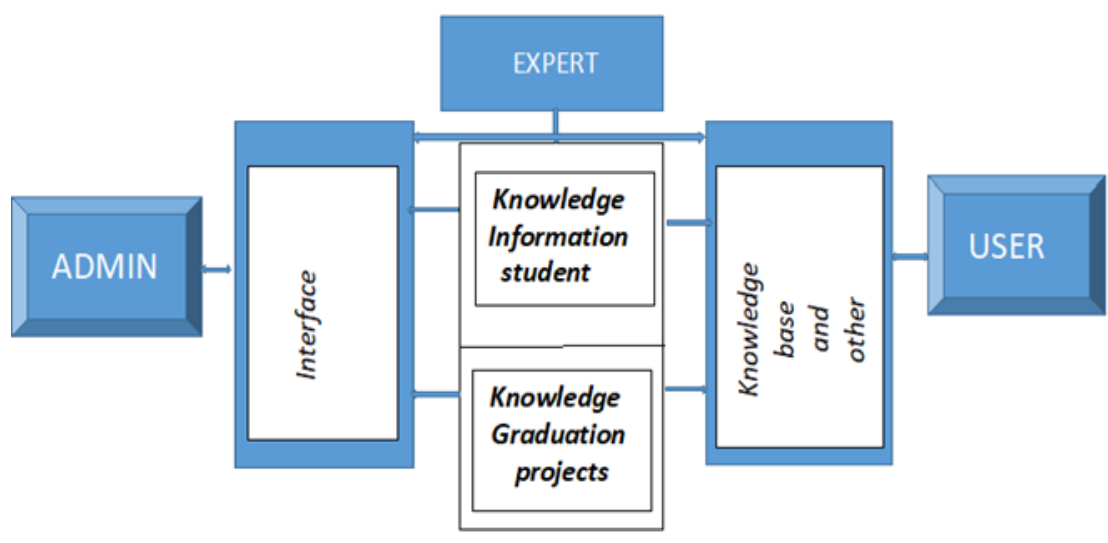

Figure 1. Structure of the knowledge base system 
The main components of the system are the knowledge base, inference engine, and a workspace. The knowledge base of the system performs a key role in the method of decision-making by efficiency storing the domain knowledge and student Information. Temporary results may be stored in the workspace. The inference engine is a program, which infers the knowledge available within the knowledge base [23-25]. Distribute student projects, the system intends to represent a common framework that implements a generally accepted basic structure of academic projects. Steps to make the system:

\subsection{Steps of students' registration for the projects}

\subsubsection{Student registration}

Each student logs into the system through the student number and the password that he receives through the system administrator, where he is a number. The student is made up of (7) numbers, such as (1204351), which is the same as the student's ID number, and the secret number is composed of (18) numbers, which are randomly generated by this function such as (435727893387780658) show in Table 1.

\subsubsection{Projects proposed by the scientific departments of the college}

All graduation projects submitted to the system are presented to the student on the projects page, which contains all the project details these are (name of supervisor, project title, main objectives of the project, brief description of the project, requirements, number of students required for the project).

\subsubsection{Student registration process on projects}

Before the registration process, if the student is the first time to enter the system, a list of skills will appear in him on the registration page at projects the student must determine the skills he possesses, and these skills are added to the student's information and based on which they are tested with the project's skills. The registration process takes place after the student determines the skills that he possesses. The student can register only by specifying the skills. After specifying the skills, each student is allowed to register on only three projects, and he is not allowed to register on more than three. To ensure the student's right, the student system can print a report that contains the student's name, student number, and projects that have been registered and also contain QR code contains the name of the student and the projects registered on it to prevent fraud and forgery in projects. Show in Figure 2.

\begin{tabular}{l} 
University of Basra \\
College of Information Technology and Computer \\
Science \\
Graduation projects registered \\
$\begin{array}{l}\text { D Student: } 1400100 \\
\text { Name Student: Majed Ahmed Aziz } \\
\text { choice (1): System of distribution of monitors to the examination } \\
\text { halls } \\
\text { Name Prof. prof Maysaa Abd UIK areem } \\
\text { choice (2): Implement some commands by distinguishing the hand gesture } \\
\text { Name Prof. prof Abbas Hanoun } \\
\text { choice (3): System of distribution of monitors to the examination halls } \\
\text { Name Prof prof. Zainab Hamid }\end{array}$ \\
\hline
\end{tabular}

Figure 2. Student registration document for the project

\subsubsection{Amending the projects of the registered person}

After giving the administration a period for its students to change their options, the student can enter this page and choose the project where. He who wants to change and replace the project he wants and uses this mechanism with the rest of the projects. After the end of the period, the page is closed, as a student cannot change his options. 


\subsubsection{Amending student information}

The student has the right to only change the skills. As for the rest of the information, it is modified by the administrator, because it is downloaded to the system automatically through a text file on the student registration page and at the same time it can be modified show in Figure 3.

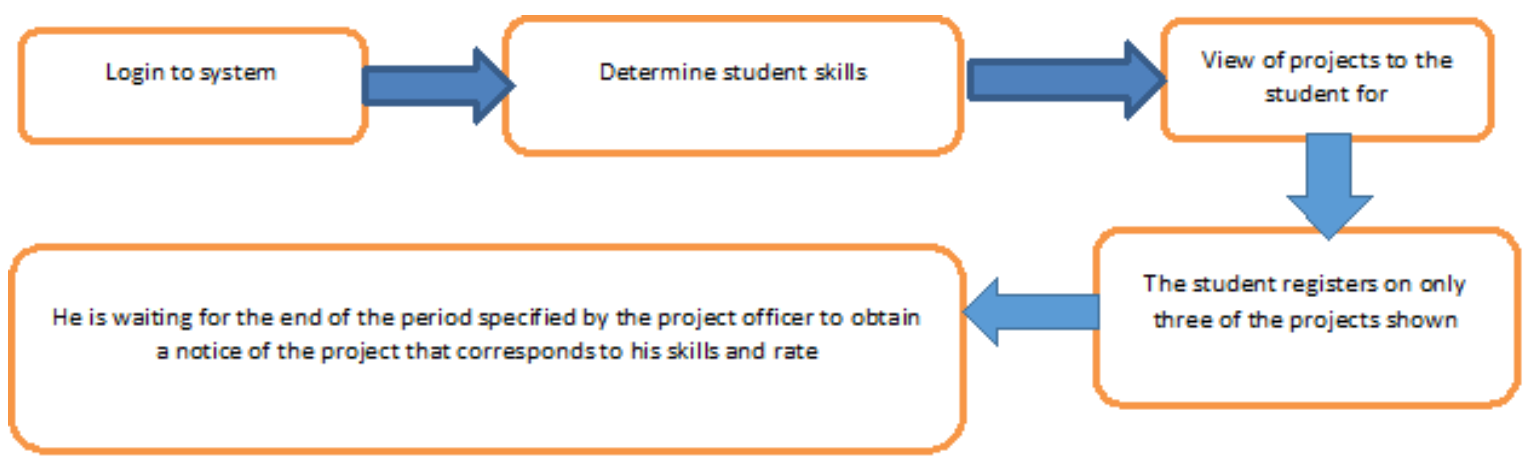

Figure 3. Illustrate the steps for student registration on the project

2.2. The powers of the person responsible for the system and the mechanism for distributing student to projects

\subsubsection{Add students}

The names of students who are entitled to register on graduation projects are entered, and they are Input process is two ways:

a. The first method: adding his application group as a single payment by receiving an excel file from the concerned authority responsible for sorting students who are entitled to register on graduation projects and transfer it to a text file, where the entry is as a text file and this type is used if the officer wants to enter his request group.

b. The second method: adding a single student, where the entry is by the administrator, he enters all the data manually and uses this type in the case of entering one student.

The student's information entry is in both cases (student number, student name, student average, and his password). Where a number is generated for each student in both ways (a random 11-digit secret number that the student uses with his number to log into the system) show Figure 4.

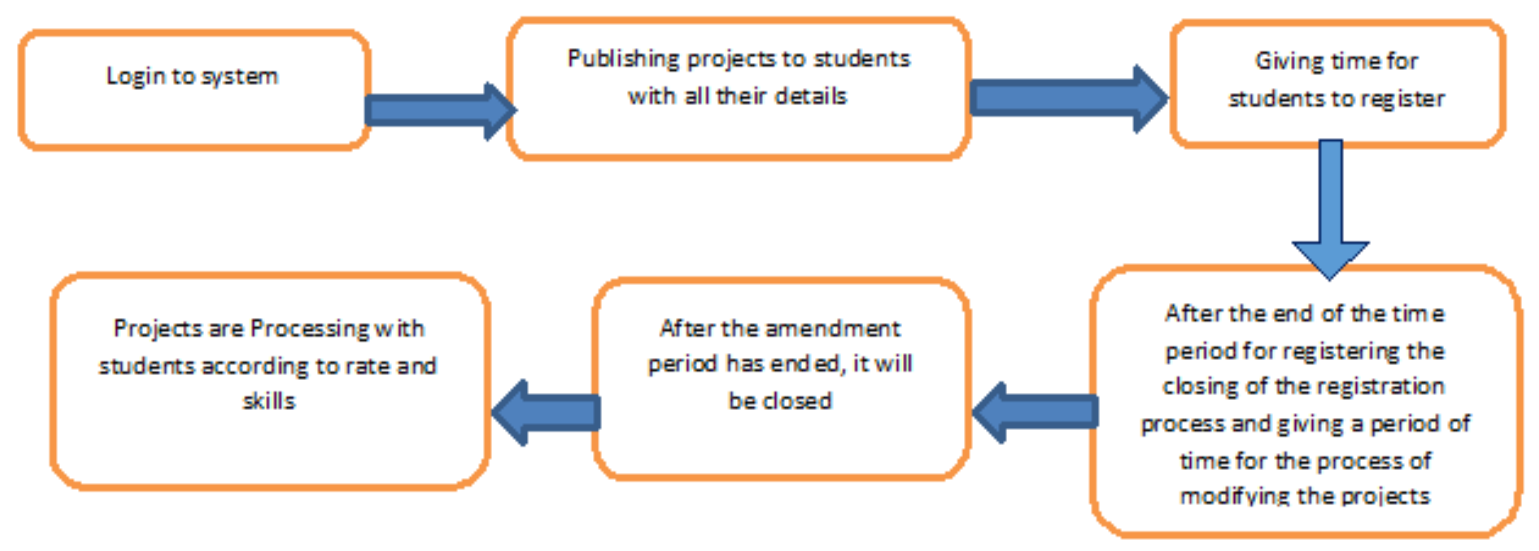

Figure 4. Illustrate the work of administer

\subsubsection{Student information}

The system contains a database for all student information that the system needs in the process of distributing graduation projects to students and includes (student number, student name, student rate, student password). Enables the system to perform: 
a. Performing student information modification or student deletions by clicking on the field you want to delete.

b. Print a report containing all students 'information. Where student numbers and secret numbers are distributed to students through this report, each student takes his password through the student number where (Each student has a unique number, "ID number", whereby a student can enter the system when he obtains the ID number and password from the report at the committee responsible for the projects). As shown in Table 1.

Table 1. Report contains all students 'information

\begin{tabular}{ccccc}
\hline NO & ID & Name student & average & password \\
\hline 1 & 1509405 & Sajad mohammed hassan & 74.3 & 456784329876462534 \\
2 & 1509489 & Hussan alaa jaber & 80.4 & 876543987698457649 \\
3 & 1508483 & Raga Majid Hameed & 77 & 648729754876937694 \\
4 & 1507848 & Alaa Qusai Nuri & 86 & 465937296587557733 \\
5 & 1508473 & Zainab Muslim Ramadan & 76 & 335566775544332299 \\
6 & 1508574 & Zahraa Maitham Abdul-Hussein & 66.8 & 114466448885557744 \\
7 & 1507584 & Majid Ali Majid & 64.4 & 555577744339965544 \\
8 & 1509371 & Ahmed Mohamed Jameel & 87 & 999944447777884466 \\
9 & 1502343 & Sarah Majed Abdul Hamid & 89 & 778888999944466666 \\
10 & 1509487 & Muhammad Qusai Raza & 68 & 555555577777444449 \\
11 & 1509732 & nabaa Muhammad Hassan & 75.3 & 887766994433555577 \\
2 & 1501230 & Ali Abbas Hassan & 65.2 & 777744444333399225 \\
13 & 1506743 & alaa Zuhair Muhammad & 74 & 993336664448855787 \\
\hline
\end{tabular}

\subsubsection{Add a project}

The system administrator enters graduation projects with full details (project title, professor name, number of students required for the project, project goals, project description, as well as the skills required for each project).

\subsubsection{Modifying project information}

The project information can be modified by searching on the title of the project to be modified, then correcting the information and clicking on the amendment button, and the project can also be deleted by clicking on the delete button.

\subsubsection{Registering students on the project and controlling the process of registering on projects}

Every student has the right to register on three projects published by the system administrator. The registration process for projects and the process for modifying projects are controlled through a control panel where a specific period of time is given to the students to complete the registration process on projects. When the specified period ends, the system administrator can lock the registration process as the student cannot register. As well as giving a specific time to students to process the amendment of student options and when the specified period ends the system administrator can lock in the modification process as the student cannot amend the project data.

\subsubsection{The process of distributing projects to students}

Projects are distributed to students according to controls and conditions, whereby the distribution depends on the student's average rate and the student's second-class skills and number students required for each project. But each of the above conditions depends on the other condition to conduct the project distribution process.

\subsection{Steps of project distribution}

STEP1: Students are ranked from the highest rate to the lowest rate through the database using language SQL STEP2: The skills required for the project are compared with the skills that the student possesses, and to achieve the requirement that the student accepts the project that the student chose in the previous entry process, he must possess half of the skills required for the project Provided that it includes at least one programming language example (c ++, java, PHP, c \#, etc ...).

STEP3: The required number for each project is examined and based on the required number, students are added to the project and upon reaching the required number the student is transferred to the second project registered on it and so on, the mechanism of action of the system:

1. Students' skills and the skills required for each project are retrieved. 
2. Chopping down all skills and storing them in a matrix to facilitate the comparison process through evidence explode.

3. For the comparison process, calculate the number of skills for each student and project.

for $(\$ \mathrm{i}=0 ; \$ \mathrm{i}<$ count Project; $\$ \mathrm{i}++)$

for $(\$ j=0 ; \$ j<\$$ count Student; $\$ \mathrm{j}++)$

if $(\$$ cut Project $[\$ i]==\$$ cut Student $[\$ j])$

\$counter $+=1$

4. Compare the number of similar skills for a student with the skills required for a project if the number of skills possessed by the student is equal to at least half the number of skills required in the project, provided that only one programming language is available to the student in order to be qualified on the project registered on it. The information is saved in its array.

if $((\$$ counter/2) $>=$ \$count Project $) \& \&$ (\$cut Student[\$i] == "c++" ||\$cut Student[\$i] == "c\#"

||\$cut Student $[\$ i]==$ "php" $\|$...)

\$data [] = array('id'=> \$row['id_sudent'],

'id_project' => \$row['id_project'],

'required number' $=>$ \$row ['required number']);

5. Before adding the student to the project, check the required number for the project. If the required number of the project is incomplete, the student will be added to the project. If it is incomplete, the student will transfer to another project from which the projects are registered.

If (Required Number of project $<=$ Count project in Data)

Add ();

Else Tested on Another Project ();

6. In the last stage before adding any student with his project to the database, check the database with the student not already present to avoid duplication of data. The official can print a report containing the final distribution of projects on students with full details (the name of the supervisor and the student involved with the project and the required number) shown in Table 2.

Table 2. The final distribution of projects on students

\begin{tabular}{|c|c|c|c|c|c|}
\hline No & ID & Name Student & Project of Student & Supervisor & $\begin{array}{l}\text { Required } \\
\text { Number }\end{array}$ \\
\hline 1 & 1509405 & $\begin{array}{l}\text { Sajad mohammed } \\
\text { hassan }\end{array}$ & $\begin{array}{l}\text { System of distribution of monitors to the } \\
\text { examination halls }\end{array}$ & Zainab Hamid & 3 OF 1 \\
\hline 2 & 1509489 & Hussan alaa jaber & $\begin{array}{l}\text { System of distribution of monitors to the } \\
\text { examination halls }\end{array}$ & Zainab Hamid & 3 OF 2 \\
\hline 3 & 1508483 & Raga Majid Hameed & $\begin{array}{l}\text { System of distribution of monitors to the } \\
\text { examination halls }\end{array}$ & Zainab Hamid & 3 OF 3 \\
\hline 4 & 1507848 & Alaa Qusai Nuri & Student absences system & $\begin{array}{l}\text { Talib Abdul } \\
\text { Samad }\end{array}$ & 4 OF 1 \\
\hline 5 & 1508473 & $\begin{array}{l}\text { Zainab Muslim } \\
\text { Ramadan }\end{array}$ & Student absences system & $\begin{array}{l}\text { Talib Abdul } \\
\text { Samad }\end{array}$ & 4 OF 2 \\
\hline 6 & 1508574 & $\begin{array}{l}\text { Zahraa Maitham } \\
\text { Abdul-Hussein }\end{array}$ & $\begin{array}{l}\text { Auxiliary systems for the unit of } \\
\text { registration and student affairs }\end{array}$ & $\begin{array}{l}\text { Alaa Khalaf } \\
\text { Hammoud }\end{array}$ & 3 OF 1 \\
\hline 7 & 1507584 & Majid Ali Majid & $\begin{array}{l}\text { Auxiliary systems for the unit of } \\
\text { registration and student affairs }\end{array}$ & $\begin{array}{l}\text { Alaa Khalaf } \\
\text { Hammoud }\end{array}$ & 3 OF 2 \\
\hline 8 & 1509371 & $\begin{array}{l}\text { Ahmed Mohamed } \\
\text { Jameel }\end{array}$ & The Questions Bank & $\begin{array}{l}\text { Asaad Abdul } \\
\text { Karim }\end{array}$ & 1 OF 1 \\
\hline 9 & 1502343 & $\begin{array}{l}\text { Sarah Majed Abdul } \\
\text { Hamid }\end{array}$ & $\begin{array}{l}\text { Comparative study and analysis of the } \\
\text { methods for indexing the DNA database }\end{array}$ & Rana Majeed & 2 OF 2 \\
\hline 10 & 1509487 & $\begin{array}{l}\text { Muhammad Qusai } \\
\text { Raza }\end{array}$ & $\begin{array}{l}\text { System for distributing graduation } \\
\text { projects to students }\end{array}$ & $\begin{array}{l}\text { Maysa Abdul } \\
\text { Karim }\end{array}$ & 3 OF 1 \\
\hline 11 & 1509732 & $\begin{array}{l}\text { nabaa Muhammad } \\
\text { Hassan }\end{array}$ & $\begin{array}{l}\text { Comparative study and analysis of the } \\
\text { methods for indexing the DNA database }\end{array}$ & Rana Majeed & 2 OF 1 \\
\hline 12 & 1501230 & Ali Abbas Hassan & $\begin{array}{l}\text { Auxiliary systems for the unit of } \\
\text { registration and student affairs }\end{array}$ & $\begin{array}{l}\text { Alaa Khalaf } \\
\text { Hammoud }\end{array}$ & 3 OF 3 \\
\hline 13 & 1506743 & $\begin{array}{l}\text { alaa Zuhair } \\
\text { Muhammad }\end{array}$ & $\begin{array}{l}\text { System for distributing graduation } \\
\text { projects to students }\end{array}$ & $\begin{array}{l}\text { Maysa Abdul } \\
\text { Karim }\end{array}$ & 3 OF 2 \\
\hline
\end{tabular}

\section{DISCUSSIONS}

The higher education strip worldwide has largely integrated information and communication technologies into general teaching and learning practices. The goal of the system can be discussed in two ways: Firs, The influence of the expert system on student guidance. Second, The expert system's influence on the Projects Committee and its students' supervisors. The expert system can assist students in identifying and taking a decision on the appropriate project and enable the supervising committees to explore students'

Design an expert system for students graduation projects in Iraq ... (Maysaa Abd Ulkareem Naser) 
understanding, knowledge, directions, intentions, and technical capabilities. This paper presented a web based distribution graduation-project management system. The impulse behind the implementation of such a system has been the realization of the important role of the graduation project for preparing students to the real world, and probe of the number of administrative tasks involved on the part of faculty members and students. For that reason, the manual procedure for distributing graduation projects to students has been replaced by an automated system for managing and distributing projects graduation show in Figure 5 .

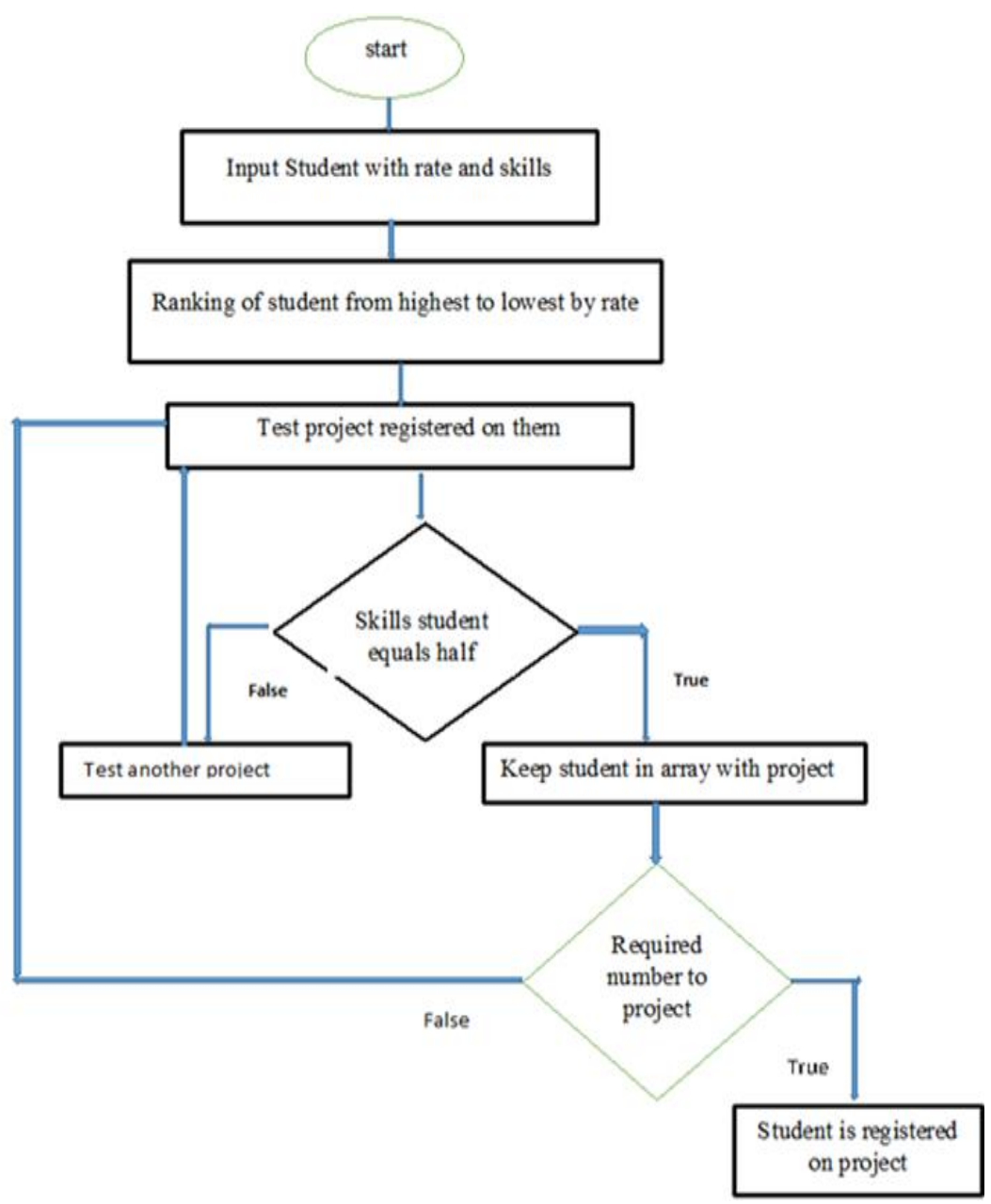

Figure 5. Diagram represents the flow of system operations

This system has some limitations where the students can`t change the project after distributed projects for students via the system and Difficult to Determine the "best graduation project based on the student's Interests. In spite of this, the system has many advantages due to its importance and urgent need in the university which includes:

a. Coordinating and managing the processes of the graduation project course.

b. Solve conflict in the projects, meaning choosing more than one group for the same project.

c. The system provides security for the student by obtaining a printed report containing the QR code containing the student's personal information in addition to the three options that he chose within the projects presented.

d. Develop Knowledge Base System to distribute graduation projects to students at the University of Basrah Reducing all (administrative) procedures and related processes.

e. Increasing effectiveness and developing performance in technical operations and information services.

f. Easy and fast information management.

g. Eliminate the factor of the direct relationship between the two parties to the transaction or reduce it to the maximum extent possible, which leads to limiting personal effects and influence. 
h. It is more economical than it is in the traditional system, as there is no need to print project selection forms and distribute them to students.

i. Reducing time and effort as students do not need to come to college to receive a form to choose graduation projects and deliver them after filling them.

j. Canceling the paper system and replacing it with the electronic system because of its flexibility and the ability to quickly correct the errors that occurred.

\section{CONCLUSION}

The system is designed at the University of Basra for students who are obligated to submit a project that qualifies them to graduate from the university. The system has achieved the basic idea that depends on the principle of distributing student projects based on the student's programming skills and the student has a rate that qualifies for the project The system performs well. result of the system helped in the following ways: (1) it simplifies interactions with the domain experts; (2) it reduces the complexity; (3) it provides effective modularization. The idea on which the expert system" Graduation Project" is built has sizeable potential, and the opportunity to develop and improve. as future work, you can add social network analysis in competition-based learning. Can develop the system as future work by adding: (1) Add guidelines for college students, wherein the projects committee can post recommendations for students. (2) Permit supervisors to create one listing of tasks, to be used as a template for a multitude of different projects. (3) Add a news bar, wherein the Head of the Graduation Committee could, for example, placed up updates concerning new regulations, or modifications to the undertaking timeline, etc. (4) Allow the Head of Graduation Committee to place up progress evaluations for students and supervisors to fill out and ship lower back over the system; Implement the automated event handler subsystem.

\section{REFERENCES}

[1] B. Bakhshinategh, et al., "A Course Recommender System based on Graduating Attributes," in Proceedings of the 9th International Conference on Computer Supported Education, Porto, Portugal, vol. 1, pp. 347-354, 2017.

[2] A. Khelifi, et al., "Graduation Project Online Management System ALHOSN University Case Study," in Proceedings of the 10th WSEAS international conference on Software engineering (SEPADS'11), pp. 130-137, 2011.

[3] S. Ivanov, et al., "Analysis of College Students' Graduation Projects," Article in SSRN Electronic Journal, pp. 31-38, 2011.

[4] I. M. Nasser and S. S. Abu-Naser, "Web Application for Generating a Standard Coordinated Documentation for CS Students' Graduation Project in Gaza Universities," International Journal of Engineering and Information Systems, vol. 1, no. 6, pp. 155-167, 2017.

[5] D. G. Hendra, et al., "Digital library of expert system based at Indonesia technology university," International Journal of Advanced Research in Artificial Intelligence, vol. 4, no. 3, pp. 1-8, 2015.

[6] H. K. Jabbar and R. Z. Khan, "Survey on Development of Expert System in the Areas of Medical, Education, Automobile and Agriculture," in 2015 2nd International Conference on Computing for Sustainable Global Development (INDIACom), pp. 776-780, 2015.

[7] S. M. H. Mousavi, et al., "A PSO fuzzy-expert system: As an assistant for specifying the acceptance by NOET measures at PH. D level," Artificial Intelligence and Signal Processing Conference (AISP), pp. 11-18, 2017.

[8] N. N. Stella, et al., "Expert System as Tools for Efficient Teaching and Learning Process in Educational System in Nigeria," International Journal on Future Revolution in Computer Science \& Communication Engineering, vol. 3, no. 12, pp. 165-168, 2017.

[9] Mayadevi N., et al., "A Review on Expert System Applications in Power Plants," International Journal of Electrical and Computer Engineering (IJECE), vol. 4, no. 1, pp. 116-126, 2014.

[10] H. Samin and T. Azim, "Knowledge Based Recommender System for Academia Using Machine Learning: A Case Study on Higher Education Landscape of Pakistan," IEEE Access, vol. 7, pp. 67081-67093, 2019.

[11] V. Hecke T., "Fuzzy Expert System to Characterize students," PRIMUS, vol. 21, no. 7, pp. 651-658, 2011.

[12] P. Kaur, et al., "Fuzzy rule based students' performance analysis expert system," International Conference on Issues and Challenges in Intelligent Computing Techniques (ICICT), pp. 100-105, 2014.

[13] M. Kuehn, et al., "An Expert System for the Prediction of Student Performance in an Initial Computer Science Course," 2017 IEEE International Conference on Electro Information Technology, pp. 1-6, 2017.

[14] L. E. Sánchez, et al., "Development of an Expert System for the Evaluation of Students," Future Internet, vol. 8, no. 2, pp. 1-18, 2016.

[15] D. B. Sanjaya and D. G. H. Divayana, "An expert system-based evaluation of civics education as a means of character education based on local culture in the Universities in Buleleng," International Journal of Advanced Research in Artificial Intelligence, vol. 4, no. 12, pp. 17-21, 2015.

[16] M. V. Muntean, "Intelligent agent based expert system for blended learning evaluation," Networking in Education and Research (RoEduNet Conference), pp. 1-4, 2017. 
[17] M. A. Al Ahmar, "A Prototype Rule-based Expert System with an Object-Oriented Database for University Undergraduate," International Journal of Applied Information Systems, vol. 4, no. 8, pp. 38-42, 2012.

[18] S. Saraswathi, et al., "Design of an online expert system for career guidance," The International Journal of Research in Engineering and Technology, vol. 3, no. 7, pp. 314-319, 2014.

[19] H. El-Ghalayini, et al., "Graduation-project management system: A social network analysis perspective," Journal of Theoretical and Applied Information Technology, vol. 95, no. 4, pp. 1-10, 2017.

[20] P. Letouze, et al., "An Academic Project Management Web System Developed through a Software House Simulation in a Classroom," International Conference on Sociality and Economics Development IPEDR, IACSIT Press, Singapore, 2011.

[21] F. del Rio, et al., "Towards a Recommender System for Undergraduate Research," Conference: ACM Conference on Recommender SystemsAt: Como, Italy Affiliation, PUC Chile, 2017.

[22] G. Supriyanto, et al., "Application expert system career guidance for students," Journal of Physics: Conference Series, vol. 1402, no. 6, 2019.

[23] J. Xu and R. He, "Expert recommendation for trouble ticket routing," Data and Knowledge Engineering, vol. 116, pp. 205-218, 2018.

[24] H. Mezni and T. Abdeljaoued, "A cloud services recommendation system based on fuzzy formal concept analysis," Data and Knowledge Engineering, vol. 116, pp. 100-123, 2018.

[25] J. A. Oravec, "Expert Systems and Knowledge-based Engineering (1984-1991)," Internanal journal of designs for learning, vol. 5, no. 2, pp. 66-75, 2014. 